\title{
Clinical characteristics and short-term outcomes of hiv patients admitted to an african intensive care unit
}

\author{
A Kwizera ${ }^{1,2^{*}}$, J Nakibuuko ${ }^{3}$, L Ssemogerere ${ }^{1}$, E Ayebale ${ }^{1}$, P Agaba', M Nabukenya ${ }^{1}$, I Clarke ${ }^{4}$ \\ From ESICM LIVES 2015 \\ Berlin, Germany. 3-7 October 2015
}

\section{Introduction}

Highly active antiretroviral therapy (HAART) for the treatment of the human immune deficiency virus (HIV) infection has been associated with improved survival among HIV infected patients world over even among patients admitted to the intensive care unit (ICU). There are no data regarding HIV patients admitted to low-income country ICUs. We sought to identify clinical characteristics and outcomes among HIV patients in a low-income country tertiary hospital.

\section{Objectives}

We sought to identify ICU admission diagnoses and survival, to compare clinical characteristics and outcomes in patients according to survival, and to determine the predictors of survival. Our study results were compared to those of published studies in HIV infected patients admitted to the ICU in the era of HAART.

\section{Methods}

We conducted a retrospective cohort study of all HIV infected patients admitted to the ICU of a university teaching hospital in Kampala, Uganda from 2009-2014. Medical records were reviewed. Clinical variables included CD 4 count, viral load, biochemical and haematological values. Serum albumin levels, need for vasopressors, mechanical ventilation, and acute physiological and chronic health evaluation (APACHE) score were documented. The primary outcome was survival to hospital discharge. Statistical significance was predetermined in reference to a $\mathrm{p}$ value of $<0.05$.

${ }^{1}$ Makerere University College of Health Sciences, Anaesthesia and General Intensive Care, Kampala, Uganda

Full list of author information is available at the end of the article

\section{Results}

There were 102 patients. Average age of patients was 38.4 and majority were females. Average length of stay was 4 days and mortality was $57 \%$. The commonest admission diagnoses were Acute Respiratory Distress syndrome (ARDS), multi-organ failure, and sepsis. Average APACHE score was 24. Majority of patients were on HAART and most patients had a CD 4 count less than 100. Most patients were on septrin prophylaxis; mechanical ventilation and $36.6 \%$ were on vasopressors for septic shock. At multivariate analysis, APACHE II, mechanical ventilation and ARDS had a statistically significant association with mortality.

\section{Conclusions}

ICU mortality of HIV patients is higher than that seen in higher income settings. ARDS is a leading reason for admission. ARDS, high APACHE II and the need for mechanical ventilation are significantly associated with mortality.

\footnotetext{
Authors' details

'Makerere University College of Health Sciences, Anaesthesia and General Intensive Care, Kampala, Uganda. ${ }^{2}$ International Hospital Kampala, International Health Sciences University, Intensive Care Medicine, Kampala, Uganda. ${ }^{3}$ Mulago National Referral Hospital, Intensive Care Medicine, Kampala, Uganda. ${ }^{4}$ International Health Sciences University, Kampala, Uganda.

Published: 1 October 2015
References
1. Barbier F, Roux A, Canet E, Martel-Samb P, Aegerter P, Wolff M, Guidet B, Azoulay E: Temporal trends in critical events complicating HIV infection: 1999-2010 multicentre cohort study in France. Intensive care medicine 2014, 40(12):1906-1915.
2. Vincent B, Timsit JF, Auburtin M, Schortgen F, Bouadma L, Wolff M, Regnier B: Characteristics and outcomes of HIV-infected patients in the


ICU: impact of the highly active antiretroviral treatment era. Intensive care medicine 2004, 30(5):859-866.

3. Greenberg JA, Lennox JL, Martin GS: Outcomes for critically ill patients with HIV and severe sepsis in the era of highly active antiretroviral therapy. Journal of critical care 2012, 27(1):51-57.

doi:10.1186/2197-425X-3-S1-A351

Cite this article as: Kwizera et al:: Clinical characteristics and short-term outcomes of hiv patients admitted to an african intensive care unit. Intensive Care Medicine Experimental 2015 3(Suppl 1):A351.

\section{Submit your manuscript to a SpringerOpen ${ }^{\mathcal{O}}$ journal and benefit from:}

- Convenient online submission

- Rigorous peer review

- Immediate publication on acceptance

- Open access: articles freely available online

- High visibility within the field

- Retaining the copyright to your article

Submit your next manuscript at $\gg$ springeropen.com 